\title{
THE WAY OF THE PHARMACEUTICAL INGREDIENTS TO THE FINISHED PHARMACEUTICAL FORM
}

\author{
${ }^{1}$ Bence Rafael, ${ }^{2}$ Nóra Kuruczleki, ${ }^{3}$ József Gál \\ ${ }^{1}$ Faculty of Pharmacy University of Szeged, Szeged, Hungary \\ ${ }^{2}$ Faculty of Economics and Management, University of Szeged, Szeged, Hungary \\ ${ }^{3}$ Faculty of Engineering, University of Szeged, Szeged, Hungary \\ e-mail: galj@mk.u-szeged.hu
}

\begin{abstract}
The modern pharmaceutical industry is a strictly controlled area. Both national and international rules apply, but none of these deals with logistical issues arising from the manufacture of the product. Following the path of a drug, it is possible to get acquainted with the problems that arise and their solution.

The drug is much more than a common product. The drug is a product of confidence, which is provided with information. It defines its quality as well, to comply with the relevant directives and standards in the manufacture of, and that the enclosed information is sent to the user.

This requires the manufacturer, the distributor and the user to comply with it. There is no production without material handling, but GMP (Good Manufacturing Practice) does not yet have a chapter on logistics. References to handling raw materials and finished products can be found in the corresponding GMP chapters, the responsibility of the correct execution are borne by the manufacturer. In this case, the effect of the common sense prevails exponentially, keep the medicine in mind and it has to be done, that no loss, no quality deterioration is not caused by the transport, handling of such loads, storage.

It is typical that the raw material and the finished product are going through the entire site during the pharmaceutical manufacture. Starting from the warehouse, it runs through the manufacturing facilities, on the packaging, and some units go to the lab, so that eventually, in medicine form returns to the warehouse, from where it goes further in the supply chain through the pharmacies to the patients.

In our study we examine the logistics activity and problems of a small pharmaceutical company and tasks to be solved presented in the light of the theory.
\end{abstract}

Keywords: pharmacy, logistics, GMP, drug

\section{INRODUCTION}

The XCV Law of 2005 states in its $\S 1$ about ,the modification of laws regulating the pharmaceutical market that „medicine: any material or its mixture which appears as a product to prevent or heal human diseases, or materials and their mixture which are applied in or on the human body in order to establish a medical diagnosis, to restore, improve or modify a physiological function of a man by producing pharmacological, immunological or metabolic effects." [1]

However, the drug is much more than that. The drug is a product of confidence provided with information. The quality of a medicinal product is determined by whether the guidelines and regulations concerning its production are complied with or whether the provided information gets to the user.

We are not discussing the latter one but our article is giving a survey about what the pharmaceutical ingredient goes through in its manufacturing process in the pharmaceutical factory and what directions

DOI: 10.14232/analecta.2018.2.24-31 
regulate these processes. Taking an actual example (without specifying either the company or the product but following the steps of a known technological process), we are describing what logistical tasks a pharmaceutical factory has to face and how they can be solved.

\section{THE PHARMACEUTICAL INDUSTRY AND ITS REGULATION}

Hungarian pharmaceuticals are subject to many domestic, international and EU regulations. Unsurprisingly, the most important domestic law is the above mentioned $2005 \mathrm{XCV}$ Law which is referred to as Pharmaceutical Law, shortly. The scope of this law covers manufacturing, production and marketing medicines for human use. This law articulates mainly the primary conditions, legal acts and deadlines of the drug delivery chain, whilst regarding drug production, it refers to the valid European directives.

The Good Manufacturing Practice (shortly: GMP) is a continuously updated code issued by the European Committee which is implemented by the Directive 2001/83/EK of the European Parliament and Council [4]. The GMP is a soft law. Something is a soft law when it does not have a clear, generally accepted concept in a legal sense: or just taking it simply, it is „unclear”.

The GMP is exactly like this: a guideline which describes what should be taken in account when producing a medicinal product to achieve and to assure the necessary quality but it does not include how it should be done exactly. It can be seen from the fact that how often we can find expressions like ,suitable" and "adequate" in the guideline - but it is up to everyone to decide what is right for them. The directives of GMP have to be applied for the given manufacturing site in compliance with the law and the common sense.

\section{THE IMPORTANCE OF DOCUMENTATION}

Chapter 4 of the Good Manufacturing Practice is about documentation. Everybody must know the expressions like Standard Operational Regulations (or SOR) or Work instructions (or WI). Nowadays, the process control is well-regulated not only in the industry but also in branches with a developed quality assurance, like public health, trade or anything else. The SOR or the WI materialize the directives of GMP, since we can employ them to project the directives to the given manufacturing site or the given situation. [3]

In addition to the exact task fulfilment, it has another important function. Concerning pharmaceutical production, documentation makes tracking the product possible, whether it is within the manufacturing area (is it inside the sluice or has it been taken to the storage?) or what the condition of the product is (has the ointment been filled in the tubes or is it still in the ointment manufacturing equipment?).

It has a significant part in the pharmaceutical factory that drugs and pharmaceutical basic materials cannot go on without any written ,permission”. What chaos would it cause if a group leader just sitting on the forklift took $200 \mathrm{~kg}$ of yellow vaseline to produce ointment without giving any filled form or without saying it to the store-keeper! The given basic material might as well be taken to the right place but it also can happen that everybody would seek for it since it has not been documented. The right documentation tracks the path of the medicinal product from the warehouse through the production line to making it into a final product, thus it helps the manufacturers'work and it is an organic part of the quality assurance system.

DOI: 10.14232/analecta.2018.2.24-31 


\section{QUESTIONS RELATED TO GMP CHAPTERS}

As I have mentioned above, the GMP is a soft law, its content can be widely interpreted, and there can be more solutions at the same time to comply with the GMP requirements in drug production. Let's look at some examples for what is written in the GMP text and what questions it raises [2]:

1. GMP Chapter 3, PREMISES AND EQUIPMENTS

The order of interconnection of rooms has to be designed so that it can follow the logical order of the production operation, and the required level of hygiene can be reached by them.

The logical order of drug production is the following: the basic materials have to be measured with suitable scales into the proper production equipment (measuring room), the right form of the drug has to be created (operation room), the finished form of the drug has to be provided with the primary (packing room) and then with the secondary wrapping (cardboarding room), and finally, the finished product has to be taken to the storehouse.

Let's imagine a pharmaceutical factory. If we followed the above-mentioned logical order, it would be sensible if the rooms, which are suitable for the particular processes, followed each other closely. In reality, it cannot be accomplished very often because there is not enough place or not only one type of drug is produced in the given building.

It can also happen that after a renovation the order of rooms has been changed but not to such extent that it would hinder the process of drug production: the measuring room will always be before the operation and packing rooms, it would be nonsense if it were between them and the semi-finished should be taken back and forth between these rooms.

2. GMP Chapter 3, PREMISES AND EQUIPMENTS, par. 3.8

The work space and inter-production storage area are considered to be good if the equipment and materials can be arranged in an orderly and logical way, minimizing the risk of mixing different medicines or their constituent substances.

The guideline requires only the order but it does not prescribe how the stock should be stored eg. in the storehouse. Should it be a mixed storehouse or a separate storage for the basic materials and the finished products? Should we order the raw materials in alphabetical order or according to the drug they are used in? Or by the storing units (barrels on the ground on pallets, bags and boxes on the shelves)? To decide on these questions it is necessary to know the conditions of the particular manufacturing plants.

3. GMP Chapter 5, PRODUCTION, par. 5.11.

If working with dry substances or products, take all precautions to prevent dust formation and scattering.

We can prevent dust formation and scattering with several technologies which are well-known for pharmaceutical experts. The regulation makes application of any accepted method possible for us depending on which one is the most suitable.

DOI: 10.14232/analecta.2018.2.24-31 


\section{GMP AND LOGISTICS}

There is no production without transportation, still the GMP does not have a chapter on logistics. References concerning management of raw materials and finished products are hidden in the GMP chapters, it is the manufacturer who takes the responsibility for the proper implementation. In this case, the common sense has even more emphasis, we have to have the protection of drugs in sight and to act so that transportation cannot cause any loss or damage in quality.

\section{CASE STUDY}

When examining the activity of a pharmaceutical factory, not only production but quality control should be considered, as well. It is natural that you have to know the technological steps of drug production and the critical phases well, otherwise you would not be able to see in the quality control laboratory what causes deteriorations in quality. Our article does not deal with quality control and quality assurance, so we are not summing up the steps of drug production from the view of the daily routine but from a logistical aspect, and we are aiming at discovering what problems can emerge in the logistics within the production area. We are not specifying the pharmaceutical company, the actual product and its active agents, it is sufficient to know that we are following the production of an ointment of multi-active agents.

The production begins with the purchase of the active and additional ingredients. We purchase all the basic materials from certified and approved suppliers and always from the same place. We give a new identification number (number and date, in a particular format) and a yellow „Under examination” label to the incoming basic materials in the storehouse. This yellow label stays there until sampling is done and the quality control laboratory qualifies the basic material.

Sampling from the basic material is done in the sampling room. On the site of the company in question the sampling room is located inside the warehouse and its material entrance opens from the side of the sluice leading to the courtyard. And this raises the first logistical problem. At present, the practice is that the incoming materials cannot enter the storehouse without a green label, until they are stored in the area located between the sluice and the storing place. When a lot of basic materials come all in once, it causes a very unpleasant situation since it hinders the free material traffic. Now, the only solution for it is that the lab works very fast, they qualify the basic material within a day, and then it can go on to the storehouse.

The storehouse of the firm is a mixed one: basic and wrapping materials, drugs and dietary supplements are stored in one place. As a rule, only one unit of a product can be located on one pallet. However, it can happen that the packaging unit of the basic material is very small, and a whole pallet cannot be wasted on it. This problem is solved so that more items are placed in one pallet but strictly separated in order to prevent mixing.

DOI: 10.14232/analecta.2018.2.24-31 


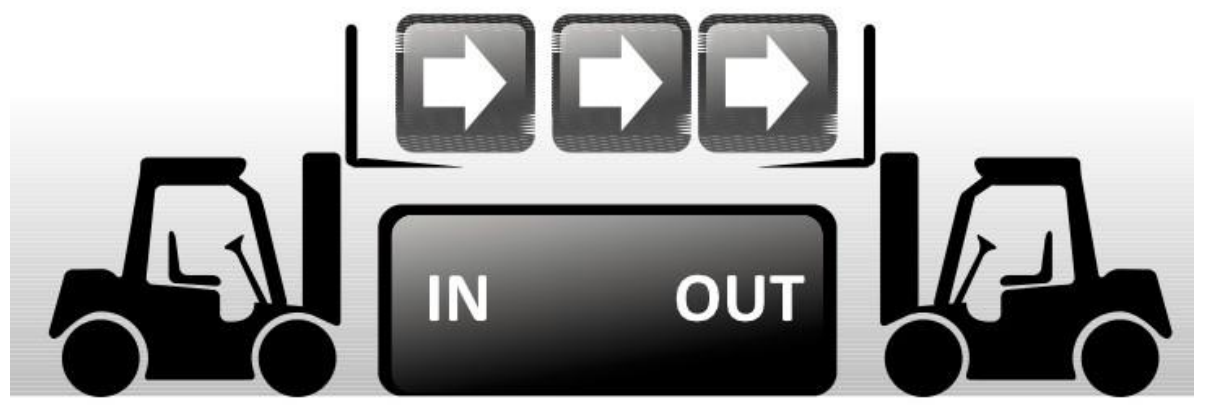

Figure 1. The FIFO-principle (Source: https://image.slidesharecdn.com/23.09.2018.)

The basic materials are taken from the storehouse on the basis of the FIFO-principle. Here, they can be tracked very easily because both basic and wrapping materials are given numbers, which makes clear that the basic material identified with a number beginning with 1992 arrived earlier than the one with 2008.

The basic materials are transported in their original wrappings on pallets with forklifts through the site to the right building. The layout of building „A” is not fully convenient: it is an old building constructed well before the GMP directives, in the 20th century, so that is why there is a corridor for the personnel wedged in between the sluice for the materials, which leads to the production area, and the courtyard. Also, because of this layout even the forklift cannot enter the building. This arrangement would make production more difficult since it would prevent moving the basic materials for the ointment in large masses, that is why it is necessary to implement two changes:

- measuring the oily basic materials of the ointment into the production equipment should not be done the oily materials of the ointment is not measured in the production equipment in solid form, but after melting them, the liquids are pumped into the ointment production equipment (note: in big pharmaceutical factories the melted ointment flows in pipelines during the whole process of production, but in this case, being a small firm, there is no opportunity to use dedicated pipes). The barrels, which contain the solid vaseline, wax, etc., are not to be taken into the production area, the door of the melting room opens to the courtyard, so it can be easily accessable with forklifts, while the basic material of the ointment does not contact the outside world, since it gets melted with heating belts without removing the top of the barrels. The tube of the pump is placed into the barrel through a small hole, thus the basic material can be pumped from the barrel in a clean and accurate way.

- Neither other basic materials of smaller quantity can be taken directly near the production area with forklifts. These are moved to the sluice for the material manually or with „frogs” where they get cleaned and then, taken to the production area.

The order of rooms in the production area corresponds to the logical order. The room for ointment production is located right next to the measuring room. The solid basic materials are measured on proper scales into plastic sacks, then in case of production of more items they are placed into separate packingcases according to the production numbers of the ointment. The building „A" has been designed to

DOI: 10.14232/analecta.2018.2.24-31 
manufacture ointment, solutions and sterile formulations, too. Each production area has a measuring room, so it is not necessary to move the measured materials all over the building. Building "B", on the other hand, has been designed for manufacturing solid formulations, but only with one measurer. The reason for it is that there is no parallel production here, while in building „A” ointment, solution and sterile drug can be manufactured at the same time.

The composition is a solution-suspension-type ointment, so there are several complex technological steps to prepare it. The suspension and the solution are made in separate utensils, and only after that they are mixed in the equipment of ointment production. As the size of a lot (batch) is not large, weighing only 150 kgs, so preparation and moving the suspension and alcoholic solution containing two active agents each cannot challenge logistics. None of them weighs more than $10 \mathrm{kgs}$, so even one single person can take it manually to the equipment of ointment production.

The prepared ,lose" ointment is filled into tubes with another equipment. We think that this process is completed, though not irregularly, in an improper way at the company. At present, it is done so that tilting the ointment producing equipment they pour the warm ointment into vessels, and then it is poured again into the feed tank of the equipment for filling ointment. It is a hard process and needs continuous attention, but there is a solution: in larger pharmaceutical factories the finished ointment is transported to the filling machine in a pipeline. Here, it is impossible to implement it because of the size of the items.

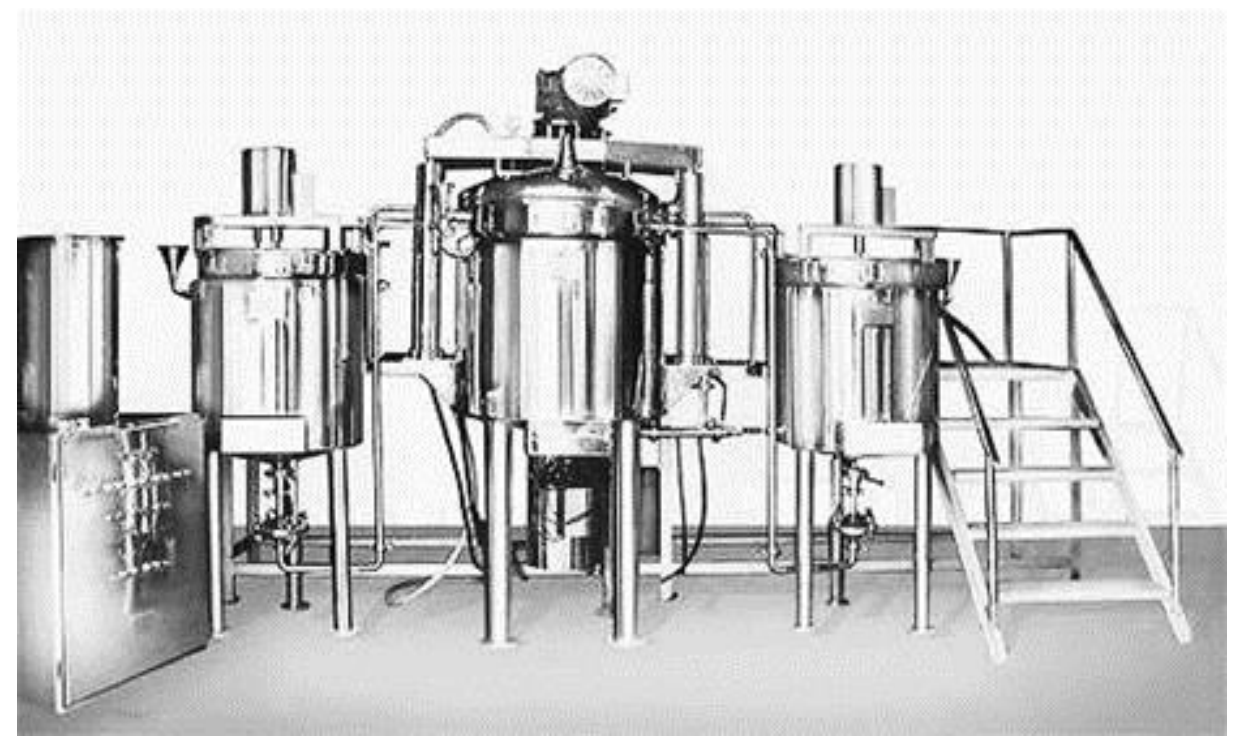

Figure 2. Industrial ointment producing equipment (Source: The Basics of Pharmaceutical Technology, Dévay A. (2013.) [5])

The ointments, then, are put into so-called akylux tubes of small size, containing around 7.500 tubes, which are transported on pallets to the storehouse with forklifts. The cardboarding room, where the drugs are

DOI: 10.14232/analecta.2018.2.24-31 
provided with information for the sick, is located inside the storehouse opening from the area behind the sluice where the basic material arrives. As we have mentioned above, it often happens that the basic materials occupy all the place making it impossible to accept new pallets. This problem is resolved improperly because the finished ointment stays in the production area, in the sluice. It does not really comply with the regulations but it can happen. Sampling for quality control can be done here, too.

The finished ointment wrapped in cardboards and provided with information leaflet is taken to the storehouse where they are placed so that the FIFO-principle can prevail. The item manufactured the earliest from each product is placed down, and the new ones are put on the shelves above. If each item from a lot has been released from the storehouse, each item of the following lot is placed one shelf down, so that it can be available according to the FIFO-principle.

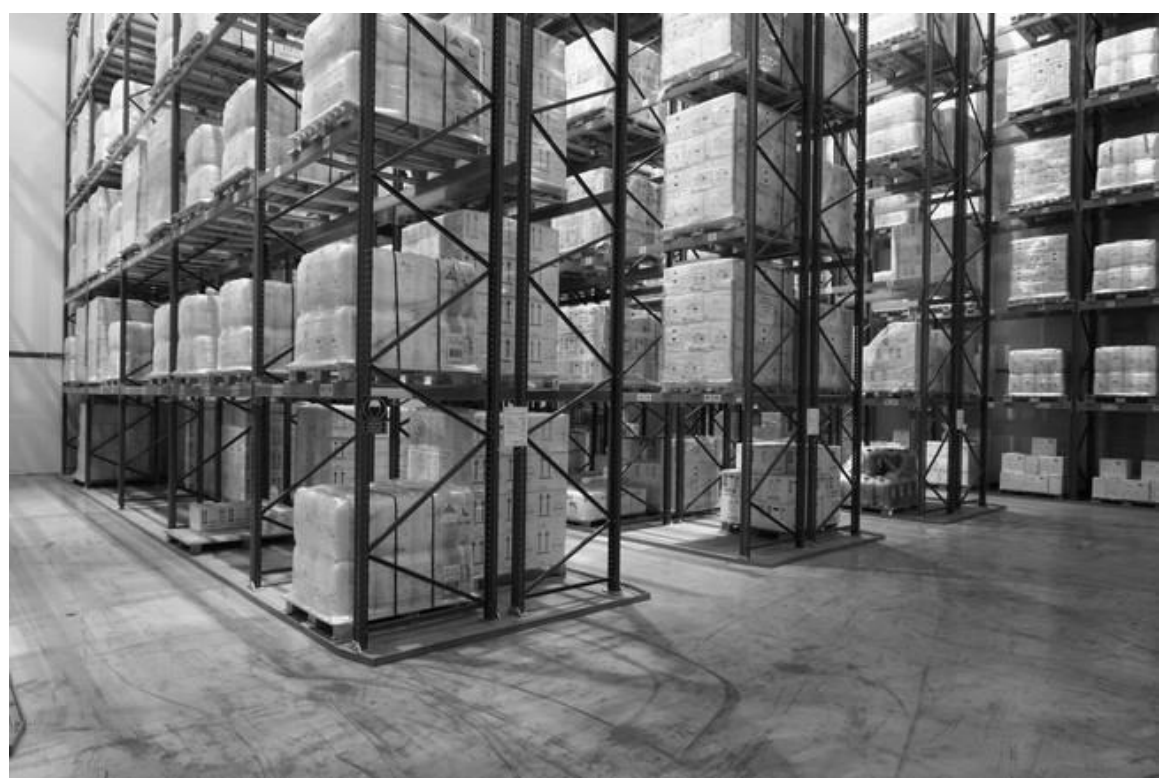

Figure 3. An example for a well-organised storehouse (ADR Logistics Kft.) (Source: http://www.adr-logistics.hu 23.09.2018.)

\section{DOCUMENTATION DURING PRODUCTION}

Documentation of the production does not begin with the Sourcing Material Claimant, but with the Sample Record following the receipt of the raw material. The regulation includes each stage of the production, a detailed Lot Form is completed for every single production item. During sales, the appropriate production certificate Quality Certificate is provided with the product.

\section{SUMMARY}

DOI: 10.14232/analecta.2018.2.24-31 
In pharmaceutical production the basic material and then the finished product moves inside the whole site. Starting from the storehouse it goes through the producing rooms, the cardboarding room, some items go to the laboratory until in the form of a product returns to the storehouse where it is carried on to the sick people in the supply chain. It is typical to this particular company that in general, it complies with the GMP guidelines, though being a small company there can be obstacles (See: the layout of building „A”) which they are not able to improve at present.

The drug industry is strictly regulated but due to its variety there can be areas which are not fully covered. Like proper logistics. Resolution of logistical problems depends on the imagination of producers and while they can protect the quality of drugs - together with the sick people- we should not worry about whether we have chosen the right method.

\section{REFERENCES}

[1] 2005. évi XCV Törvény „az emberi alkalmazásra kerülő és egyéb, a gyógyszerpiacotszabályozó törvények módosításáról"

[2] OGYI (2006): A Helyes Gyógyszergyártási Gyakorlat (GMP) irányelvei, A hatályos európai irányelv (Eudralex Volume IV) fordítása

[3] 44/2005. (X. 19.) EüM rendelet ,az emberi alkalmazásra kerülő gyógyszerek gyártásának személyi és tárgyi feltételeiről"

[4] Az Európai Parlament és a Tanács 2001/83/EK irányelve (2001. november 6.) az emberi felhasználásra szánt gyógyszerek közösségi kódexéről

[5] Dévay A. (2013): A gyógyszertechnológia alapjai, egyetemi tankönyv, PTE 